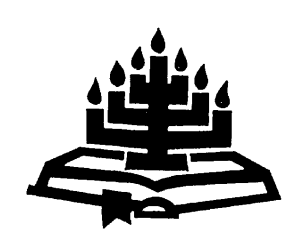

\title{
Die Heilige Gees en gebed in die erediens
}

\author{
B.J. de Klerk \\ Skool vir Kerkwetenskappe \\ Noordwes-Universiteit \\ Potchefstroomkampus \\ POTCHEFSTROOM \\ E-pos: ben.deklerk@nwu.ac.za
}

\section{Abstract \\ The Holy Spirit and prayer during the service}

Prayer in the worship service is pre-eminently a pneumatological reality: prayer is a gift from the Holy Spirit. The question that is addressed in this article is: Which decisive function does the Holy Spirit fulfil in the elements of the prayers in the worship service? Aspects that are discussed include the work of the Holy Spirit in the service events, especially in prayer and the essence of the service; the elements of the service prayer; the congregation's participation in the service prayers; and the relationship between Scripture reading and preaching to service events. The Spirit works the most intimate relationship between the prayer believers and Christ, and so with God the Father, this is the trinitarian grounds for the service prayer. Prayer entails spiritually entering God's holiness, directly addressing God, the confession of the believers and the most important part, their gratitude. In prayer it is above all about the honour of God. Elements of the worship service prayer include honour and awe for God (praise) and gratitude towards God (saying thanks), a realisation of sin and repentance (humiliation and confession of sin), invocation that can even be a lamentation, dependence and a Christian attitude of love (intercession). The relationship of Scripture reading, preaching, prayer, worked by the powerfull work of the Holy Spirit, is a causal relationship of community with God in Christ with his gathered congregation through revelation to confession and worship. 


\section{Opsomming}

\section{Die Heilige Gees en gebed in die erediens}

Die erediensgebed is by uitstek 'n pneumatologiese werklikheid: gebed is 'n gawe van die Heilige Gees. Die vraag wat in hierdie artikel aan die orde kom is: Watter beslissende funksie vervul die Heilige Gees in die elemente van die erediensgebede? Aspekte wat bespreek word, is die werk van die Heilige Gees in die erediensgebeure, veral wat betref die gebed en die wese van die erediens; die elemente van die erediensgebed; die gemeente se deelname aan die erediensgebede; en die verhouding van Skriflesing en prediking tot die erediensgebede. Die Gees bewerk die allerintiemste verhouding tussen die bidders en Christus en ook met God die Vader - dit is die trinitariese grond vir die erediensgebed. Gebed is die geestelike intree in God se heiligdom, die regstreekse aanspreek van God, die belydenis van die bidders en is die belangrikste deel van hulle dankbaarheid. In die gebed gaan dit bo alles om die eer van God. Elemente van die erediensgebed sluit eerbied en bewondering vir God (lofprysing) in asook dankbaarheid teenoor God (danksegging), sondebesef en berou (verootmoediging en skuldbelydenis), smeking wat selfs 'n klaaggebed kan wees, afhanklikheid en Christelike liefdesgesindheid (voorbidding). Die verhouding tussen Skriflesing, prediking en gebed, bewerk deur die kragtige werking van die Heilige Gees, is 'n kousale verhouding van gemeenskap met God in Christus met sy vergaderde gemeente deur openbaring tot belydenis en aanbidding.

\section{Inleiding, probleemstelling}

Soos persoonlike gebede, is gebed in die erediens in ' $n$ krisis. Daar is verskillende moontlike redes hiervoor, byvoorbeeld die taalgebruik van die voorganger, die worsteling van die erediensdeelnemer om te kan saambid, onbekendheid oor die aard van die verskillende gebede en die teologisering (oor- of voortpreek van dit wat reeds gesê is). Wie egter dieper delf, ontdek dat hierdie gebede in 'n krisis verkeer vanweë onder andere die geestelike armoede van die bidders, die Geesloosheid in die gebede, omdat die Vader en sy mag en liefde in die erediensgebede buite rekening gelaat word (Lourens, 2000:174-179). Robinson (1964:106) het reeds dekades vantevore die gebed in 'n tussenmenslike raamwerk geplaas waar die aanspreek van die "u" in die erediensgebed verwys na die ander mens, sodat die bidder hom/haar in God en God in hom/haar ken. Sölle (s.a.:105) sluit hierby aan en sê dat dit nie in die gebed gaan om verhoring deur God nie, aangesien die gebed op die medemens 
gerig is waarin die bidders hulleself uitpraat en so tot aanvaarding van hulleself kom soos hulle is. Gebed is verder 'n verwaarloosde tema in die gereformeerde teologie (Wethmar \& Brand, 2006:801). Hierteenoor is die gebed in die Nuwe Testament by uitstek 'n pneumatologiese werklikheid: die gebed is 'n gawe van die Heilige Gees en slegs verklaarbaar vanuit die gawe van die Gees aan die gelowige (Kloppers, 2003a:120). Gebed behoort immers tot die lewe van die nuwe mens, en dit is slegs die Heilige Gees wat die nuwe mens in Christus skep (Versteeg, 1973:6, 7). Vervulling met die Heilige Gees is dus vir die gebed van deurslaggewende belang (Asumang, 2008:23).

Die vraag wat in hierdie artikel aan die orde kom is: Watter beslissende funksie vervul die Heilige Gees in die elemente van erediensgebede? Aspekte wat bespreek word, is die werk van die Heilige Gees in die erediensgebeure, veral wat betref die gebed en die wese van die erediens, die elemente van die erediensgebed, die gemeente se deelname aan de erediensgebede en die verhouding van Skriflesing en prediking tot die erediensgebede.

\section{Die werk van die Heilige Gees in die erediensgebede}

Die Heilige Gees is in 'n gebedsamekoms uitgestort, en daarmee is die onlosmakende band tussen Gees en gebed gelê (Hand. 1:14 en 2:1; Barrett, 1998:89). Die verhouding tussen Heilige Gees en gebed en daarmee die gebed as gawe van die Gees word veral in Romeine 8 geopenbaar. In hierdie gedeelte is daar twee lyne. Die eerste is Romeine 8:15 waar die Gees die bidder "Abba, Vader" laat roep; hierin word die rykdom van die gebed geleer (Morris, 1992: 314). Die tweede lyn is dié van Romeine 8:26, waarin geleer word dat die Gees die bidder se swakhede te hulp kom; hierin word die menslike armoede met betrekking tot die gebed geleer (Cranfield, 2004:422).

\subsection{Abba, Vader}

Dit is onmiskenbaar dat die uitdrukking "Abba, Vader" sy oorsprong in die liturgie het, want die Aramese vorm daarvan wys op 'n vaste uitdrukking in die erediens. Die gemeente roep "Abba" wat nie as 'n ekstatiese uitroep van individue gesien moet word nie, maar as 'n gemeenskaplike aanspreekvorm deur die hele gemeente (Morris, 1992:315). Wanneer God die Gees, deur wie die bidder "Abba" roep, God so openbaar, gee die praesens van die werkwoord (roep) aan dat die gemeente van Rome hierdie aanspraak tot God reeds geken het en gewoond was om so tot God in die gebed te nader. Dit 
is dus 'n stereotiepe uitdrukking wat algemeen gebruik is, en moet veral aan die liturgiese gebruik daarvan toegeskryf word. Calvyn (1961:169) sê dat die herhaling van die woord in verskillende tale uitdruk dat God se genade nou in so 'n mate oor die wêreld versprei het, dat in alle tale van die wêreld so tot Hom gebid kan word.

Die woord Abba vind in die gemeente aansluiting by die aanroepingsvorm deur Jesus self. In die hele Ou Testament word God nêrens in die gebed as Vader aangespreek nie, en die persoonlike aanspraak "my Vader" kom ook nie in die kring van die Palestynse Jode voor nie. Die rede hiervoor is dat hierdie aanspreekvorm eenvoudig te intiem was. Daarom was dit vir Jesus se tydgenote nie net verrassend nie maar selfs opsienbarend dat Jesus God as Abba aanspreek. Die woord Abba is een van Jesus se mees eie woorde. Vir Jesus se tydgenote was dit oneerbiedig en selfs ondenkbaar om God met so 'n familiêre titel aan te spreek. In Jesus se gebruik van die woord word in die eerste plek die diepste geheim van sy lewe, sy Seunskap, geopenbaar en so openbaar Hy God ook as Vader (Cranfield, 2004:398). Die wonder is dat die Heilige Gees nou die gelowige leer om God as Abba aan te spreek. In Christus het die Gees hulle reeds en onherroeplik kinders van God gemaak en hulle mag weet dat al bid hulle vanuit die armoede van die "nog nie" van hierdie lewe, die "reeds" van die Gees in hulle waarborg dat die Vader hulle eendag alles saam met Christus sal laat erf (Coetzee, 1984:253).

Die Abba-roep kan alleen werklikheid word waar die Gees die gelowige laat deel in die volheid van die verlossing wat deur Christus geskenk is; dus waar die Gees die gelowiges hulle kindskap laat belewe. Die genade dat die gelowiges, die gemeente, "Abba, Vader" kan bid, kom tot die gelowige van die Vader deur die Seun in die Gees. Omgekeerd keer die gelowige met die roep "Abba, Vader" in die Gees, deur die Seun weer terug tot die Vader (Wethmar \& Brand, 2006:814). Juis in die kindskap-uitsprake kom die persoonlike en innige van die versoende houding met God tot uitdrukking. God stuur sy Gees in die hart van sy kinders om saam met hulle gees te getuig en so die ware gebed moontlik te maak (Lee, 2004:280).

God self neem die inisiatief in alle gebede en Hy is die diepste grond en ware bron vir die gebed. In die Persoon en werk van Jesus Christus word die aanspreek van God die Vader persoonliker en dringender. Sy verlossingswerk vorm die grond, die basis, maar ook die bron, vrymoedigheid en krag van die erediensgebed (Barnard, 1987:60). Christus is teenwoordig in die gebed omdat Hy as Midde- 
laar die gebede van die gemeente vir God aanvaarbaar maak (Lee, 2004:288). Juis omdat die gebed in sy Naam geskied en Hy daarin teenwoordig is, het die gebed groot krag. Die Gees bewerk die allerintiemste verhouding tussen die bidders en Christus en so met God die Vader. So is daar 'n trinitariese grond vir die erediensgebed (Styger \& Human, 2005:265).

\subsection{Die Heilige Gees kom ons swakheid te hulp}

In Romeine 8 handel Paulus by uitstek oor die heilshistorieseskatologiese spanning tussen die "reeds" en die "nog nie" (Morris, 1992:323). Die hele skepping en die kinders van God sug tesame om die voleinding, die nuwe skepping, die verheerliking van die kinders van God. Dit is 'n grondtrek van 'n Christen in hierdie tyd: dit is 'n sug vanweë die "nog nie" (vgl. Rom. 8:18-25). Die armoede van die erediensgebed laat die kerk sugtend vanuit die onvoltooidheid bid. In Romeine 8:26 is die sug dat die swakheid van die bidders te hulp gekom moet word, want hulle weet nie wat om te bid soos dit hoort nie. Die "te hulp kom" van die Heilige Gees (sunantilambanesthai) is 'n werkwoord waaraan twee voorvoegsels toegevoeg is. Die eerste (sun) versterk die tweede (anti), wat helpende ondersteuning tegelyk as plaasvervangende ondersteuning karakteriseer (Cranfield, 2004:421). God se genade is so groot dat Hy die bidders tot medewerksaamheid bevry (vgl. Rom. 8:15) en omgekeerd daarna met hulle saamwerk (Morris, 1992:327). Die versugtinge wat nie in woorde gesê kan word nie is die werking van die Heilige Gees in die hart van die gelowige bidders. Dit is sy gebed uit die hart van die mens tot God, waarin Hy van die swakke menslike gebed die vertolking gee wat in ooreenstemming met God se wil is (Ridderbos, 1959:191). Die Gees doen dus iets wat die gemeente nie kan doen nie, want die gebed met onuitspreeklike sugtinge lê nie binne menslike vermoëns nie.

Die sug van die Gees is anders as die sug van die skepping en die mens, omdat dit versugtinge is wat nie met woorde gesê kan word nie. God verstaan die versugtinge van die Gees, omdat Hy daarin die volvoering van sy eie voornemens onderken (Versteeg, 1973: 30). Prakties beteken dit vir die erediensgebed dat die volle nadruk moet val op die feit dat die gebed deur die Heilige Gees gewerk word. Die geestelike ingesteldheid van die biddende gemeente vanweë hulle swakheid, die sonde in hulle, is nederigheid en armoede. Tog, omdat hulle bewus is dat die Heilige Gees in hulle werk en Hy die gebed volgens die bedoeling van God voor Hom lê, moet daar ook vrymoedigheid en blydskap in die gebed wees (Cranfield, 
2004:422). So word in die erediens die weg tot gebed deur die Heilige Gees gebaan, en daarom kan die gebed in die gemeente waar die Gees woon, nooit verwaarloos word nie.

Die beslissende saak in enige gebed is dat dit "in die Gees" is. "In die Gees" beteken dat dit onder beheer van die Gees is, met die Gees vervul is en deur die Gees gelei word (Asumang, 2008:27). Die Heilige Gees stuur en lei die gebed, skep die gebed in die bidders en bekragtig hulle om dit uit te spreek (Wethmar \& Brand, 2006:811). Die Gees is die Gees van wysheid en openbaring, want Hy verlig die oog van die bidder om God te ken, asook die Gees van Christus wat langs die weg van geloof, hoop en liefde die skatte van die verbond in Christus ontsluit (Best, 1998:605). Om "in die Gees" te bid is om kinderlik God as Vader te ken en in eerbied en vertroue innig met die Vader te praat en tegelyk ook bewus te wees dat die woorde wat die gemeente uitspreek deur die Gees geheilig en tot in die Vaderhart ingedra word (Moritz, 1996:185).

\section{Die gebed en die wese van die erediens}

Die gebed in die erediens is, soos reeds gesê, in 'n krisis, want dikwels verskyn voorbidders en bidders sonder enige ontroering voor God en sonder dat daar enige spanning in die bidders op te merk is. Dikwels word die gebed in die liturgie in die skaduwee van die preek gestel, omdat die moeë prediker geestelik uitgeput en leeggepreek in die lof- en dankgebed voorkom (Spoelstra, 2004:273). Dit blyk meermale dat erediensdeelnemers wel na preke luister, maar dit is 'n vraag of die gemeente hartlik saamgebid het.

Die Woord roep gebed in die samekoms van die gemeente op (Clemens, 2006:27). Sonder gemeenskap met die Woord van God kan daar geen gebedsgemeenskap ontstaan nie. Die Woordgemeenskap is vir die gebedslewe 'n kwessie van lewe of dood. Wat is die gebed dan?

Gebed is die geestelike intree in God se heiligdom, die regstreekse aanspreek van God, die belydenis van die bidders en die belangrikste deel van hulle dankbaarheid. Die samekoms van die gelowiges kan in 'n sekere sin ook 'n gebedsamekoms genoem word. Die wonder van die gebed is dat die gemeente wat uit verskillende persoonlikhede bestaan, almal met een stem en een hartsgesindheid met God kan praat. Die gebed is daarom liturgies onmisbaar en staan in die ontmoeting met God liturgies ten minste gelyk aan die prediking (Oberle, 2008:56). 
In die erediensgebed openbaar die gebede van die gemeente, kollektief in hulle ontmoeting met God in die gemeente, 'n gesprekskarakter (Lourens, 2000:6). Kommunikasie in die erediens, ook in gebede, geskied in 'n pastorale konteks wat gerig is op heling en genesing, en daarom kan die gemeente deur hierdie kommunikasie tot aktiwiteit gebring word. Die doel van kommunikasie in die erediens is die ontmoeting van God met die gemeente, waardeur die ontmoeting van die gemeente met God en met mekaar moontlik gemaak word (Vos \& Pieterse, 1997:24). Binne so 'n konteks kan dialoog in onderlinge begrip en 'n mate van konsensus oor baie dinge ontwikkel. Waar gelowiges in die erediens in God se teenwoordigheid God en mekaar ontmoet, kan houdings, persepsies en optredes verander (Williams, 2007:229). Dialoog is 'n proses wat soos 'n spiraal na bo beweeg op die weg van dieper insig, meer groei, groter onderlinge begrip en meer betrokkenheid by mekaar en die persone en aangeleenthede waaroor in die gebed gepraat word (Vos \& Pieterse, 1997:26). Gebed word ingedeel volgens die semantiese domein van kommunikasie (Du Rand, 1990:36). Ten opsigte van genoemde woordgroep kom Louw en Nida (1988:409) tot die volgende konklusie: "The most generic expression for prayer may simply be to speak to God". Wanneer ten behoewe van iemand anders gebid word, tree die voorbidder as bemiddelaar op (vgl. byvoorbeeld Ef. 6:18) en betoon hy/sy liefde wat 'n uitwerking op die bidders se optrede kan hê.

Gebed is egter nie net kommunikasie nie, maar ook gemeenskap met God (Louw, 2001:66), met die medebidders en met dié wat in die gebed aan God opgedra word. God stig communio en maak sodoende gebed moontlik. In sy almag en alomteenwoordigheid het God nie ons gebede nodig nie, "but He wants [it,] thanksgiving and intercession, as the entering of his creatures into his loving will, by which He created human light in his communiation of Himself" (Cullmann, 1995:143). Gelowiges bevind hulle deur die gebed in God se liefde en dit beteken dat God diegene liefhet vir wie ons bid - oneindig meer as wat óns hulle liefhet (Cullmann, 1995:143).

Dit gaan in die gebed bo alles om die eer van God. Juis daarom is dit verkeerd om die gebed te misbruik om nie met God in gesprek te wees nie, maar om die gemeente deur gebede te probeer motiveer. Die Fariseërs wat op straathoeke hardop gebid het om mense te beïnvloed, is afstootlik vir die gelowige van vandag, maar die voorganger in die erediensgebed kan ook dieselfde sonde doen as hy/sy die gebed misbruik om daardeur die gemeente toe te spreek en selfs te probeer manipuleer (Cullmann, 1995:123). Die aard van die 
erediensgebed as kommunikatiewe handeling in die erediens is geleë in die reaksie van die hoorders op die spreker. Lidmate in die erediens moet kan verstaan wat in die gebede gesê word (1 Kor. 14:15) sodat hulle deelnemend kan saambid, anders kan hulle nie instemmend verklaar dat hulle hulle daarmee vereenselwig of daaraan deelneem en daardeur tot aksie aangespoor word nie (Lourens, 2000:32).

Hartstogtelike klagtes en sugte in gebede ruk ontredderde bidders (Ps. 77) en geloofsgemeenskappe (Ps. 74, 79 en 137) se wonde oop. Hierin word die angs en frustrasie, die moeite, nood en pyn van mense hoorbaar. Herstel, genesing en betrokkenheid kan dan by die gemeente intree, omdat God as Geneesheer sy oë en hande op stukkende lewenswonde hou (Human, 2001:63). In sowel die liturgie as in die sosiale betrokkenheid van die kerk binne die samelewing kan die ontbloting in die gebed ' $n$ rol speel om verandering te bemiddel.

Van Zyl (2001:380) sê die oorkoepelende doel van gebed is die eenwording van die gelowige met God en sy wil. In die Nuwe Testament is die Heilige Gees die Gebedsmiddelaar wat die diepste roersels van ons denke deurgrond en dit in ooreenstemming bring met God se wil (Rom. 8:26, 27). Die krag van gebed blyk ook daarin dat God gebede in ag neem by die volvoering van sy oordele (Op. 8:3-4) en daarom bring gebede aksie by die bidders en by God. Gemeenskap met God beïnvloed die bidder (Louw, 2001:80). Hierdie beïnvloedingsgebeure moet egter nie as gebedsmanipulasie gesien word nie, want dit gaan nie bloot oor die behoeftes van die mens nie, maar oor die krag wat gemeenskap met God in die lewe van die bidder uitoefen. Die bidders se innerlike word in aanraking gebring met 'n objektiewe werklikheid: die heil in Christus as 'n aanduiding van 'n nuwe toestand van verlossing en bevryding. Die bidders word deur hierdie bevryding beweeg tot uiting van die liefde wat uit die verlossing spruit (Williams, 2007:229).

In die erediensgebed word bidders deur gemeenskap met God bekragtig met die verlossing en bevryding in Christus (Lee, 2004: 280). Die bidders word deur hierdie bevryding beweeg tot uiting van liefde wat uit die verlossing voortspruit. Dit gaan dus oor die krag wat gemeenskap met God in die lewe van die bidder uitoefen. Gebed beskik oor die krag om bidders deur die inwerking van die Heilige Gees sensitief te maak vir die persone en sake waarvoor God geloof, gedank en gesmeek word en waarvoor daar skuld bely word (Parrish, 1996:241). 
Vir ware aanbidding is die vereiste dat dit Geesbepaald en Christusmatig moet wees - Christusmatig in die sin dat die aanbidding getrou moet wees aan dit wat in Christus geopenbaar is. Die gebedsingesteldheid moet volgens Johannes 4:23-24 in Gees en in waarheid en met 'n kinderlike gesindheid geskied (Du Toit, 1994: 273). Dit beteken verder egte onbaatsugtige Godgerigtheid, Godsvertroue en vergewingsgesindheid. Ander riglyne vir aanbidding in die erediens sluit eerbied en bewondering vir God (lofprysing) in en dankbaarheid teenoor God (danksegging), sondebesef en berou (verootmoediging en skuldbelydenis), smeking (wat selfs 'n klaaggebed kan wees), afhanklikheid en Christelike liefdesgesindheid (voorbidding; vgl. Du Toit, 1994:273).

\section{Die elemente van die erediensgebed}

\subsection{Die gebed om die verligtende werk van die Heilige Gees}

Die gebed om die verligting van die Heilige Gees, die epiklese, het via die Oosterse kerk die betekenis gekry dat die Gees ingeroep word om die brood en wyn in die werklike liggaam en bloed van Christus te verander. Die Reformasie het die epiklese vrygemaak van sy konnotasie as bede om verandering van die elemente van die Nagmaal en het dit weer sy besondere plek voor die preek gegee (Barnard, 1981:556). In Calvyn se liturgie van Genéve is die aanhoor van die Skrif en die preek voorafgegaan deur 'n gebed om verligting. Hierdie gebed was ' $n$ bede om die verkondiging van die Woord in die hart en lewens van die hoorders in te dra (Troeger, 2006:1248). Weens die swakheid van die mens moet vooraf gebid word dat die Woorddiens waarlik opening, ontsluiting en toepassing van die Woord sal wees, dat die gemeente dit as God se Woord sal aanneem en dat die Woord vrug sal voortbring. Die bede om verligting gaan nie bloot om die prediking nie, maar moet veral op die lees en die hoor van die Skrif gerig word. Die gemeente weet dat die oopgaan van die Woord in sy midde 'n wonder van God se Gees is, en nou vra hulle dat hierdie wonder hier en nou sal gebeur.

\subsection{Lofprysing in die erediensgebed}

Dit is opmerklik dat in elke erediensgebed ' $n$ redelike sterk mate van danksegging en smeking (ook voorbidding) voorkom, maar dat lofprysing en opregte skuldbelydenis twee aspekte van die erediensgebed is wat maklik verwaarloos word (Lourens, 2000:184). Lof kan beskou word as 'n erkenning van wie God is (sy deugde) en dank as erkenning vir dit wat God skenk en doen (sy dade). Lof is die hart van Bybelse gebede en kan getipeer word as die sentrale doel van 
alle gebed (O'Kennedy, 2000:543). Dit wys op die sleutel van alle ware godsdiens: die erkenning van God as God (Viljoen \& Floor, 2004:760). Aan God behoort alle mag en daarom kan Hy diegene bekragtig wat nie meer verder kan of wil gaan nie. Hy is die Lewe, die Skenker van die nuwe lewe in Christus (Janse \& Hendriks, 2002:74). God is die Skepper wat diep by ons geskiedenis en ons teenswoordige lyding betrokke is. God is liefde en Hy buig Hom in liefde neer na gebroke mense en diegene wat deur ander gestigmatiseer word (Kgosikwena, 2001:213). Vir hierdie eienskappe van God, moet Hy geloof word.

Die grootheid, goedheid en heiligheid van God moet in die erediens opgevang word en deur bemiddeling van Christus en in gemeenskap van die Heilige Gees in diepe erkenning weer aan God teruggegee word (Maré, 2005:1275). Eers nadat die gemeente werklik na God in sy Woord geluister het, kan die lofprysing en aanbidding tot sy reg kom. Juis omdat die lofprysing uit die openbaring van God wakker gemaak word, is dit noodsaaklik dat hieraan dringende aandag gegee moet word (Viljoen \& Floor, 2004:759). Die lofprysing is baie sterk persoonlik en daarom is ' $n$ innige gemeenskapslewe met God voorwaarde vir hierdie element in die erediensgebed. Die lofprysing is die innigste en hoogste vorm van aanbidding, en daarom moet die gemeente verlang om daarin deur oefening te groei (Styger \& Human, 2005:268).

\subsection{Danksegging in die erediensgebed}

Danksegging is baie nóu verwant aan lofprysing (Janse \& Hendriks, 2002:74. Dit is veral baie duidelik uit 1 Korintiërs 14:16, waar Paulus eulogein (loof, prys) en eucharistia (danksegging) vir dieselfde handeling gebruik (so ook eucharistia en doxazein (verheerlik) in 2 Kor. 9:12, 13). In Efesiërs 5:20 word die danksegging (in die raam van liturgiese handeling) aan die vervulling met die Heilige Gees verbind. ' $n$ Onvergenoegde gees is in botsing met die werking van die Heilige Gees. Daarom sê Calvyn (1965:204) dat dit ondankbare luiheid is as die erediensdeelnemers nie dwarsdeur hulle lewe dankbaarheid aanleer en beoefen nie. Die Heilige Gees roep deur die openbaring van God in Christus dankbaarheid op, en die vormgewing van die nuwe lewe in Christus kry in die danksegging sterk gestalte.

In die dankgebede word God gedank vir sy reddingsdade, sy hulp, beskerming en genadegawes (Human, 2001:61). God se reddingsdade trek saam in die lewe, sterwe, opstanding en voorspraak van sy Seun. Die dank oor God se dade gaan dus ook oor die patos wat 
Hy betoon het in die kruis van Jesus Christus. God is in sy goedheid altyd gereed om dit wat goed is aan mense te gee, en die klimaks van sy gawes, as vrug van die oorwinning van Christus oor die doodsmagte, is die Heilige Gees. Die Gees sug saam met die lydende en bring die onuitgesproke versugtinge van die persoon wat nie weet hoe en wat om te bid as gevolg van die nood en pyn van sy/haar siekte, in ooreenstemming met God se wil voor sy genadetroon. Die gemeente het dus in die erediensgebede oorvloedige stof tot dankbaarheid, veral omdat gelowiges ten behoewe van ander met vrymoedigheid na Hom kan gaan (Van Zyl, 2001:384).

Die gemeente moet, terwyl hy God dank, bewus wees dat die stem van die bepaalde gemeente in die danksegging met die stem van die gelowiges in die hemelse heerlikheid verenig (Versteeg, 1976: 46).

\subsection{Verootmoediging, skuldbelydenis en vergewing in die erediensgebed}

Die skuldbelydenis kan maklik verskraal tot 'n "vergewe ons ons sonde, om Christus ontwil, Amen". Dan is dit nie veel meer as 'n afsluitingsformule van die gebed nie. Die gebed kry hiermee 'n sombere toon, omdat dit nie met 'n lofverheffing in die teenwoordigheid van Christus eindig nie. Maar indien die gemeente in die Skriflesing en prediking God se teenwoordigheid weer ontdek het en onder die besef van sy heiligheid gekom het, sal die Heilige Gees die gebed van skuldbelydenis oproep (Williams, 2007:227). In die Ou (Spr. 28:13) en Nuwe Testament (1 Joh. 1:9) is daar sterk oproepe en aanmoediging tot skuldbelydenis.

In die verootmoediging van 'n gemeente voor God is ' $n$ belangrike erkenning dat lidmate medesondaars is (Muller, 2006:656). Gemeentes moet ook die sonde van die gemeenskap, die sonde van die nasie op hulle neem. Jesaja bely nie net dat hy self sondig is nie, maar dat hy onder 'n sondige volk woon (Jes. 6:5; vgl. ook Neh. 1:57). Die bidders moet die Heilige Gees smeek om berou in hulle wakker te maak oor die sondige lewenstyl in die gemeente en in die gemeenskap (Troeger, 2006:1246). Uit die berou sal hartgrondige skuldbelydenis volg, wat die voorganger in ootmoed en deur identifisering met ander sondaars behoort uit te spreek. Die Here beloof dat opregte skuldbelydenis deur vergewing gevolg sal word en daarom sal die bidders self onmiddellike vergiffenis ervaar en 'n nuwe verhouding met God word daardeur gekonstrueer (Human, 2001:61; Venter, 2005:414). Enige gebed vir die land, die kontinent en die wêreld moet deur hartgrondige skuldbelydenis gedra word. Die 
gebed van verootmoediging moet ook die perspektief open op die verwagting dat vanuit die ellende, die koninkryk sal aanbreek en daarmee die volle vrede, geregtigheid en heerlikheid in eskatologiese sin sal bring (Smit, 1997:448).

Die belydenis in die erediens moet in kort volsinne geskied, sodat die gemeente kan saambid. Dit moet konkreet, maar nie persoonlik nie, eenvoudig en kinderlik wees. Die voorganger moet met sy taal en stemtoon iemand wees wat midde-in die skuld staan.

\subsection{Voorbidding in die erediensgebed}

Die Heilige Gees wek deur die Woorddiens by die gemeente ootmoed om hulle nood, begeertes en behoeftes aan God bekend te maak. Die vrymoedigheid om as priesters vir die gemeente, die kerk in die wêreld, die mense wat in nood is en vir die wêreld self voorbidding te doen, word eweneens gewek (Kloppers, 2003b:143). Hulle het toegang tot die heilige troon van God en kan dus tot God nader (Heb. 10:22). Eers wanneer die gemeente homself opnuut in die spieël van die Woord gesien het en dieselfde Woord die wêreld met sy node werklik leer ken het, kan voorbidding op die beste wyse gedoen word (Williams, 2007:225). Die gemeente het een groot sekerheid ten opsigte van die gebed, en dit is dat God sy grootste gawe, die Heilige Gees, gee aan dié wat sonder ophou om die Gees bid en vir Hom dank (Luk. 11:13). Die gebed om die Gees sluit ook die gawes en vrug van die gees in.

Voorbidding is om 'n beroep op die oorwinningskrag van Christus te doen en dan die ander met sy nood in die kragveld van Christus se oorwinning in te dra. Voorbidding handel oor die intree ten behoewe van 'n ander en is in die Bybel soms vir 'n individu, óf vir die volk, óf vir die hele gemeente, óf vir die heidene/nasies (Jer. 14:1-15:2; Joh. 17:1-26; Rom. 15:30; O'Kennedy, 2000:544). Die bidders vra om God se ingrype in 'n situasie en pleit om redding in 'n krisis. In hierdie noodsituasie word die uitsigloosheid beklemtoon, die bidders se onvermoë om iets daaraan te doen en afhanklikheid van God word voor Hom bely en God se reddingskrag word veronderstel (Human, 2001:64).

Voorbidding gerig op die kerk, fokus veral op die verkondiging van die Woord, die verstaan daarvan en die voortgang van die evangelie. Voorbidding sluit ook gebed vir die vyand in, want solank God nog sy son oor sý en die kerk se vyande laat opgaan, mag hulle nie in die voorbidding van die gemeente verbygegaan word nie (Troeger, 2006:1247). In die erediensgebed moet gebid word om 'n oop 
oog vir mense wat worstel met skuld en daardeur van God en medemens vervreem word, en vir die genade om aan 'n bediening van versoening gestalte te gee. In die gebed moet gevra word vir die gesindheid van Christus wat leer dat ander hoër as jyself geag moet word, en dat gelowiges soos Christus bereid sal wees om aan die "melaatses" van vandag te raak en hulle in te skakel (Kgosikwena, 2001:214).

\subsection{Voorbereiding vir die erediensgebede}

In die voorbereiding van gebede is die voorganger se persoonlike gemeenskap met God en sy omgang met die Woord van deurslaggewende belang. Dit beteken dat die voorbidder gedurende die week, benewens sy Skrifstudie en persoonlike gebede, ook geleentheid vir meditasie met die oog op erediensgebede moet inruim.

Die gebede wat ernstig soek na God se wil, gaan met baie worsteling gepaard. God kan in sy almag soms sy plan verander, soos by Hiskia (2 Kon. 20:1-6) en by Jona (Jona 3:3-10), maar soms ook nie, soos Jesus se gebed in Getsemane dat die lydensbeker moet verbygaan (Mark. 14:36,39; Viljoen, 2004:636) en by Paulus se gebed oor die doring in die vlees (2 Kor. 12:1-10). Daar is geen teenstrydigheid tussen God se soewereine heerskappy en sy openheid om na die gebede van die gemeente te luister nie (Van Zyl, 2001:387). Paulus het die grense van wat hy kon vra - die wil van God, spesifiek omtrent lyding - nie by voorbaat geken nie; hy moes dit biddende leer. Die Christelike gebede wat in die Nuwe Testament aangetref word, is algaande gevorm deur 'n teologie van die kruis, waar gebedsverhoring nie soseer bestaan in die toestaan van versoeke nie, maar in die openbaring van God se genade en krag in swaarkry (Van Zyl, 2001:389).

\section{Die gemeente se deelname aan die erediensgebed}

Die Heilige Gees werk in die voorbidder en gemeente en verenig hulle in gebed. Uit elkeen van die elemente in die erdiensgebed, asook die bede om die verligtende werk van die Heilige Gees, blyk dat dit nie die voorganger se gebede is nie, maar die gemeente s'n en dat die voorganger die gebed as lid van die gemeente bid (Redman, 2004:40). Moontlike probleme in die saambid kan by die gemeente, maar ook by die voorbidder wees. Die gemeente kan in die gebed voor God verskyn sonder dat daar diep ontroering te bespeur is, of sonder dat die gebed die minste spanning in die lewe van erdiensdeelnemers bring. Dit is moontlik al die eerste treë op die pad van formalisme. Die gemeente sal dalk nog oor preke praat, 
maar daar bestaan 'n armoede aan die bespreking van gebede, selfs met die voorganger (Kloppers, 2003a:125). Die probleem kan ook by die voorganger lê, want die gemeente is dikwels nie in staat om die gebed te volg nie, wat nog daaraan deel te neem (Lourens, 2000:179). Omdat die gebede soms onsamehangend is, bemoeilik dit die saambid van die gemeente.

In die erediens is die gemeente 'n gemeenskap van bidders, ' $n$ ecclesia orans. Om werklik as gemeente te kan bid, moet die gemeente in 'n nuwe en lewende verhouding met die Here leef. Die voorbidder lei 'n korporatiewe handeling van gebed. Omdat die liturg die mond van die gemeente is wat liturgies self bid, mag die gebed nie die persoonlike gebed van die liturg wees nie (Spoelstra, 2004:273). Hy is ook nie die gebedsmiddelaar vir die gemeente nie, daarom moet hy/sy saam met en vir hulle bid. Die voorganger moet hom/haar inleef in en saamvoel met die gemeente se lof, skuld, dank en smeking. In die mate wat die inlewing van die voorbidder slaag, verhoog dit die moontlikheid dat die gemeente saam kan bid (Styger \& Human, 2005:265). Dan luister die erediensdeelnemers nie meer na die gebed van die liturg nie, maar dan bid hulle saam in sy/haar woorde. Indien die erediensgebed vir die voorganger 'n kuns is, dan sekerlik veel meer vir die erediensdeelnemers - 'n heilige kuns wat alleen deur die Heilige Gees moontlik gemaak kan word (Heyns, s.a.:40).

'n Uiters belangrike voorvereiste vir verenig in gebed is opregtheid van sowel die voorbidder as die saambidders. Liturg en erediensdeelnemers moet daarteen waak om vir die skyn (Mark. 12:40) te bid. Hulle moet eers bid om te kan en te mag bid, voordat hulle saam die openbare gebed bid. ' $n$ Paar oomblikke van stilte sal aan almal die geleentheid gee om deur die werking van die Gees hulle op waaragtige gebed in te stel.

Hoe kan die gemeente saambid? Die eerste vereiste is dat die gemeente aktief na die gebed luister en dit sinsnede vir sinsnede volg. Maar dit is nie genoeg nie. Die gemeente en die liturg moet ' $n$ onderlinge instelling op die gang en elemente van die gebed hê. Daarom moet die gemeente weet dat die gebed saamgestel is uit lofprysing, danksegging, skuldbelydenis en smeking en voorbidding. Sodoende kan die gemeente saam met die liturg die oorgange van die een element na die ander maak. Saambid is veral bevestiging van wat deur die voorbidder, as mond van die gemeente, uitgespreek word (Redman, 2004:41). In die Nuwe-Testamentiese tyd was daar vaste formules wat bevestiging uitgedruk het, en dit het so in die vroeë kerk praktyk gebly. Die wisselwerking tussen voorbidder 
en gemeente was baie hoorbaarder as vandag. Telkens het die volle gemeente hardop gesê: "Dit is so, amen", of ander vaste formules uitgespreek. Deur opreg, in die hart, sonder steuring van ander op gegewe momente van hierdie formules gebruik te maak, bewys die saambidder dat die gebed die gemeente se gebed is.

Die deelname van die gemeente aan die erediensgebede omvat die voorbereiding vir die gebed, gebed vir die persoon wat in die gebed voorgaan, en veral die "amen" op die gebed. Lidmate behoort opgevoed te word om gedurende die voorafgaande week die voorbidder te skakel in verband met besondere redes vir lofprysing, skuldbelydenis, danksegging en smeking en voorbidding. Tydens die samekoms voor die erediens moet spesifiek gevra word watter aspekte in die gebede aangeraak moet word. Die saambid in die erediens kan grootliks versterk word indien die woord "amen" in die regte lig gesien word. Die meeste erediensdeelnemers ervaar "amen" as 'n plegtige kerklike manier waarmee die voorganger die einde van sy/haar gebed aan die "luisteraars" bekend maak. Die Hebreeuse woord se grondgedagte is dat 'n saak bekragtig word. Die "amen" bekragtig nie hier die eie woord nie, maar die woord van 'n ander word daarmee aanvaar en oorgeneem. Dan is die gebed ten volle deur die gemeente oorgeneem (Lourens, 2000:178).

Wat vir die saambid van die gemeente van belang is, is dat almal wat aan die erediens deelneem dieselfde gebedshouding moet inneem. Die feit dat manlike erediensdeelnemers staan en vroulike deelnemers sit, kom enersyds uit die destyds beskikbare fasiliteite van die reformatoriese kerke en andersyds uit 'n piëtistiese gees wat berus op ' $n$ verkeerde interpretasie van 1 Korintiërs 11:7, 8. Daarvolgens word geredeneer dat mans en vroue verskillende gebedshoudings as onderskeidingsteken in die erediens moet inneem. Hierdie gebruik dat mans staan en vroue sit, is onlogies en teologies nie te verantwoord nie (Barnard, 1981:561). Uiteraard is die innerlike gesindheid van die hart baie belangrik, maar die bewuste liggaamlike ekspressie in die psigomatiese eenheid van die mens is ' $\mathrm{n}$ belangrike aspek van die deelname in die openbare gebed. In die $\mathrm{Ou}$ en Nuwe Testament is die gebed nie alleen 'n saak van woorde nie, maar van die hele liggaam. Die hele mens, ook volgens sy liggaamlikheid, is in die Skrif by die gebed betrokke. 


\section{Die verhouding van Skriflesing, prediking en gebed in die erediens}

Die Heilige Gees skep deur middel van die verskillende handelinge 'n verhouding tussen elkeen van die handelinge en sorg vir die eenheidslyn wat dwarsdeur die erediens loop, naamlik die ontmoeting van God met sy volk. Die Gees roep deur die Woorddiens (die Skriflesing en die prediking) die gebed in die hart van die gemeente wakker. Daar bestaan dus 'n sterk band tussen Skriflesing, prediking en gebed in die erediens. Die primaat van die Skriflesing in die erediens bring mee dat prediking en gebed alleen op grond van die Skriflesing kan plaasvind (Clemens, 2006:27). God het sy genade in die gestalte van die Woord bekend gemaak, en in die suiwer prediking kom God se woorde in mensewoorde na die gemeente (Pieterse, 2005:417). Christus is in die prediking teenwoordig en $\mathrm{Hy}$ handel daarin. Prediking is daarom nie bloot 'n gesprek oor God nie, maar dit is God Self wat deur die boodskap en die gawes van die prediker werk. 'n Skrifgedeelte is nie behoorlik gehoor en verstaan as sy verband met die aktuele konkrete situasie in die gemeente nie herken is nie. Die kommunikasievraag in die prediking word daardeur bepaal of die mense God deur die mond van die prediker met hulle hoor praat het. Prediking is in hierdie opsig 'n knooppunt in die erediens (De Klerk, 1987:301).

Die Heilige Gees is in die Woorddiens en in die diens van die gebede werksaam. Tog staan die Woorddiens en gebede nie op 'n presiese gelyke vlak nie. Die gebed het, ten opsigte van die Woorddiens, 'n dienende funksie. Omdat die Heilige Gees op dieselfde verligtende wyse in die prediking en gebed werk (nie deur inspirasie soos by die Skrif nie) en omdat sowel die prediking as gebed belydenisdiens is (nasê van die Woord) en omdat die prediking en gebed, anders as die Skriflesing, die gemeente se verantwoordelikheid is, het die prediking en gebed, in liturgiese sin, gelyke status (Troeger, 2006:1242). Die een handeling in die verhouding van Skriflesing, prediking en gebed vloei uit die ander voort en die een handeling roep die ander op. Daarom kan daar van 'n kousale verhouding gepraat word. Die Skriflesing is die een selfstandige handeling en die ander twee staan in 'n kousale verhouding tot die Skriflesing, want die Skriflesing is wesenlik openbaring: Skriflesing baar prediking en gebed (Wethmar \& Brand, 2006:812). Die prediking en gebed staan liturgies in 'n gelyke verhouding met mekaar en daarom is daar 'n wedersydse wisselwerking van die een op die ander. Die prediking, as belydenis, wek gebed as aanbidding en die aanbidding roep weer belydenis op (Maré, 2005:1283). 
Samevattend kan die verhouding van gebed met die Skriflesing en prediking soos volg weergegee word: Die verhouding van Skriflesing, prediking en gebed, bewerk deur die kragtige werking van die Heilige Gees, is 'n kousale verhouding van gemeenskap met God in Christus met sy vergaderde gemeente, deur openbaring tot belydenis en aanbidding (De Klerk, 1987:316).

\section{Ten slotte}

Die erediensgebed is by uitstek 'n pneumatologiese werklikheid: die gebed is 'n gawe van die Heilige Gees. Die Gees bewerk die allerintiemste verhouding tussen die bidders en Christus en so met God die Vader en dit is die trinitariese grond vir die erediensgebed. Gebed is die geestelike intree in God se heiligdom, die regstreekse aanspreek van God, die belydenis van die bidders en die belangrikste deel van hulle dankbaarheid. Dit gaan in die gebed bo alles om die eer van God. Elemente van die erediensgebed sluit eerbied en bewondering vir God (lofprysing) in en dankbaarheid teenoor God (danksegging), sondebesef en berou (verootmoediging en skuldbelydenis), smeking (wat selfs 'n klaaggebed kan wees), afhanklikheid en Christelike liefdesgesindheid (voorbidding).

\section{Geraadpleegde bronne}

ASUMANG, A. 2008. Be filled with the spirit and not with wine: echoes of the messianic banquet in the antithesis of Ephesians 5:18. Conspectus: the journal of the South African Theological Seminary, 5:21-38.

BARNARD, A.C. 1981. Die erediens. Pretoria: NG Kerkboekhandel.

BARNARD, A.C. 1987. Die lewende gebed in die erediens. (In Smuts, A.J., red. Perspektiewe op die erediens: praktiese teologie in Suid-Afrika. Pretoria: NG Kerkboekhandel. p. 58-70.)

BARRETT, C.K. 1998. A critical and exegetical commentary on the acts of the apostles. Edinburgh: Clark. (The international critical commentary.)

BEST, E. 1998. A critical and exegetical commentary on Ephesians. (In Emerton, J.A., Cranfield, C.E.B \& Stanton, G.N., eds. The international critical commentary. Edinburgh: Clark.)

CALVYN, J. 1961. The epistles of Paul the apostle to the Romans and to the Thessalonians. Grand Rapids: Eerdmans.

CALVYN, J. 1965. The epistles of Paul the apostle to the Galatians, Ephesians, Philippians and Colossians. Grand Rapids: Eerdmans.

CLEMENS, D.R. 2006. The norm. Liturgy, 21(2):25-34.

COETZEE, J.C. 1984. Die Heilige Gees in die prediking van Paulus. (In Du Toit, A.B., red. Handleiding by die Nuwe Testament. Band 5: Die Pauliniese briewe. Pretoria: NG Kerkboekhandel. p. 242-273.)

CRANFIELD, C.E.B. 2004. A critical and exegetical commentary on Romans 18. London: Clark. (The International critical commentary.)

CULLMANN, O. 1995. Prayer in the New Testament: with answers from the New Testament to today's questions. London: SCM. 
DE KLERK, B.J. 1987. Die Heilige Gees en die verhouding Skriflesing, prediking en gebed in die erediens. Potchefstroom: PU vir CHO. (Th.D.proefskrif.)

DU RAND, J.A. 1990. Enkele kernmomente oor gebed in die Nuwe Testament. Nederduitse Gereformeerde teologiese tydskrif, 31(1):35-46.

DU TOIT, A.B. 1994. Liggaamstaal in gebed: 'n Nuwe-Testamentiese perspektief. Skrif en kerk, 15(2):264-279.

HEYNS, J.A. s.a. Die sin van die erediens. Bloemfontein: Sentrale Pers.

HUMAN, D.J. 2001. Gebed: 'n proses wat verandering bemiddel. Verbum et ecclesia, 22(1):58-71.

JANSE, R. \& HENDRIKS, H.J. 2002. Die gebruik van lofprysing in die aanbidding van God. Nederduitse Gereformeerde teologiese tydskrif, 43(1 \& 2):71-75.

KGOSIKWENA, K.B. 2001. Pastoral care and the dying process of people living with HIVIAIDS: speaking of God in a crisis. Missionalia, 29(2):200-219.

KLOPPERS, E.C. 2003a. Veni, veni, o Oriens ... die erediens as kommunikatiewe handeling gerig op oriëntering, uitdrukking, verandering en verbintenis. In die Skriflig, 37(1):115-127.

KLOPPERS, E.C. 2003b. Singend is die geloof in sy element ... gemeentesang as kommunikatiewe handeling. Acta theologica, 23(2):136-145.

LEE, D. 2004. In the spirit of truth: worship and prayer in the gospel of John and the early fathers. Vigiliae Christianae, 58:277-297.

LOURENS, P.K. 2000. Gebed as kommunikatiewe handeling in die erediens. Potchefstroom: PU vir CHO. (Th.M. verhandeling.)

LOUW, D.J. 2001. 'n Teologie van gebed: kommunikasie as communio en dank. Acta theologia, 2:65-84.

LOUW, J.P. \& NIDA, E.A. 1988. Greek-English lexicon of the New Testament based on semantic domains. Goodwood: United Bible Societies.

MARÉ, L.P. 2005. Psalm 103: lofprysing word gebore uit die swaarkry van die lewe. Hervormde teologiese studies, 61(4):1273-1284.

MORITZ, T. 1996. A profound mystery: the use of the Old Testament in Ephesians. Leiden: Brill.

MORRIS, L. 1992. The epistle to the Romans. Grand Rapids: Eerdmans.

MULLER, B.A. 2006. The role of worship and ethics on the road towards reconciliation. Verbum et ecclesia, 27(2):641-663.

OBERLE, J.P. 2008. Understanding prayer, worship and religious ritual. Generations, 32(2):55-56.

O'KENNEDY, J.F. 2000. Gebed in die Ou en Nuwe Testament: 'n vergelykende studie. In die Skriflig, 34(4):535-555.

PARRISH, V.S. 1996. Praying as reformed Christians. Encounter, 57(3):231243.

PIETERSE, H.J.C. 2005. Die rol van Godskennis in die ontmoetingsgebeure met God in die prediking. In die Skriflig, 39(3):409-422.

REDMAN, R. 2004. Worship wars or worship awakening? Paradigms, perception and worship innovation. Liturgy, 19(4):39-44.

RIDDERBOS, H.N. 1959. Aan de Romeinen: commentaar op het Nieuwe Testament. Kampen: Kok.

ROBINSON, J.A.T. 1964. Eerlijk voor God. Amsterdam: Buijten \& Schipperheijn.

SMIT, E.J. 1997. Die voorkoms en betekenis van gebede in die Ou Testament. In die Skriflig, 31(4):437-451. 
SÖLLE, D. s.a. De waarheid is concreet. Amsterdam: Buijten \& Schipperheijn.

SPOELSTRA, B. 2004. Het die reformasie die leer gered en aanbidding verloor? Acta theologica: teologiese, historiese en wetenskaps-filosofiese studies binne reformatoriese kader, supplementum, 5:270-291.

STYGER, P. \& HUMAN, D. 2005. Om die Psalms biddend te sing of singend te bid. In die Skriflig, 39(2):255-271.

TROEGER, T.H. 2006. A house of prayer in the heart: how homiletics nurtures the church's spirituality. Hervormde teologiese studies, 62(4):1239-1249.

VAN ZYL, H.C. 2001. Drie probleemareas in gebed: 'n perspektief vanuit die Nuwe Testament. Hervormde teologiese studies, 57(1 \& 2):379-396.

VENTER, P.M. 2005. Penitential prayers in the books of Baruch and Daniel. Old Testament essays: Festschrift James Alfred Loader. Special issue, 18(2):406-425.

VERSTEEG, J.P. 1973. De Heilige Geest en het gebed. Kampen: Kok. (Apeldoornse Studies, 11.)

VERSTEEG, J.P. 1976. Het gebed volgens het Nieuwe Testament. Amsterdam: Buijten \& Schipperheijn. (Zicht op de Bijbel, 10.)

VILJOEN, F.P. 2004. Gebed in die lewe van Jesus volgens die Lukasevangelie. In die Skriflig, 38(4):623-641.

VILJOEN, F.P. \& FLOOR, L. 2004. Gloria in excelsis as liturgiese model vir die Christelike lied. Nederduitse Gereformeerde teologiese tydskrif, 45(3 \& 4):751-762.

VOS, C.J.A. \& PIETERSE, H.J.C. 1997. Hoe lieflik is U woning. Pretoria: Raad vir Geesteswetenskaplike Navorsing.

WETHMAR, C.J. \& BRAND, S.J.P. 2006. Die logika van die geloof: gebed as raakpunt tussen rasionaliteit en ervaring by Rahner en Calvyn. Nederduitse Gereformeerde teologiese tydskrif, 47(3 \& 4):799-817.

WILLIAMS, D.T. 2007. Praying through kenōsis. Acta theologica, 27(2):221233.

\section{Kernbegrippe:}

erediensgebede

gebed, deelname aan

gebed, elemente van

Heilige Gees

verhouding: Skriflesing, prediking, gebed

\section{Key concepts:}

Holy Spirit

prayer, elements of

prayer, participation in

relationship: Scripture reading, preaching, prayer

worship service prayers 
